\title{
DIGLOSIA
}

Terakreditasi Sinta 3 | Volume 3 | Nomor 2 | Tahun 2020 | Halaman 115-124

P-ISSN 2615-725X | E-ISSN 2615-8655

http://diglosiaunmul.com/index.php/diglosia/article/view/25

\section{PENGEMBANGAN BAHAN AJAR MENULIS DESKRIPSI MENGGUNAKAN MODEL KOOPERATIF ROUND TABLE DENGAN MEDIA AUDIO PADA SISWA KELAS X SMA}

\author{
Development of Descriptive Writing Teaching Material Using Round Table \\ Cooperative Models with Audio Media for Tenth Graders of Senior High School
}

\author{
Siti Halijah ${ }^{1, *}$, Susilo², Widyatmike Gede Mulawarman ${ }^{3}$ \\ ${ }^{1}$ Magister Pendidikan Bahasa dan Sastra Indonesia, FKIP, Universitas Mulawarman \\ ${ }^{2,3}$ Universitas Mulawarman \\ Pos-el korespondensi: andizahira03@gmail.com
}

\begin{abstract}
The purpose of this study is to produce teaching materials that can enhance the creativity of the learning process, increase development and improve the quality of the application of the development of cooperative models of the type of Round Table with audio media in improving the learning outcomes of writing the description of class X high school students. This research is a research development or Research \& Development (R\&D). Research and Development is a research method used to produce certain products and test the effectiveness of these products. The results of the study can be concluded from the analysis of teaching material scores by material expert teachers and media expert teachers obtained an average score of 4.74 or $94.74 \%$ of the maximum average score of 5.00 with a very good collection. The application of the development of teaching materials in the excellent category is 29 or $90.62 \%$ of the students' attention to the material delivered and student activity is included in the excellent category of 30 or $93.75 \%$ of students. The quality of the application of the development of cooperative learning model teaching materials of the round table type in learning 100\% with very good assessment and the results of post-test analysis of $96.87 \%$ indicate whether the learning tools used have practical qualities and the learning devices developed have effective qualities according with student completeness of more than $75 \%$.
\end{abstract}

Keywords: development, writing descriptions, round table cooperative model

\begin{abstract}
Abstrak: Tujuan penelitian ini adalah untuk menghasilkan bahan ajar yang dapat peningkatkan kreativitas proses pembelajaran, peningkatan pengembangan dan meningkatkan kualitas penerapan pengembangan model kooperatif tipe Round Table dengan media audio dalam meningkatkan hasil pembelajaran menulis deskripsi siswa kelas X SMA. Penelitian ini merupakan penelitian pengembangan atau Research \& Development (R\&D). Research and Development adalah metode penelitian yang digunakan untuk menghasilkan produk tertentu dan menguji keefektifan produk tersebut. Penelitian pengembangan ini menghasilkan bahan ajar berupa LKS berbasis Round Table pada materi menulis deskripsi dilakukan dengan mengacu pada model pengembangan 4$\mathrm{D}$ yang terdiri dari tahap define (pendefinisian), design (perancangan), develop (pengembangan), dan disseminate (penyebaran). Hasil penelitian bahan ajar oleh guru ahli materi dan guru ahli media diperoleh skor rata-rata 4,74 atau 94,74\% dari skor rata-rata maksimal 5,00 dengan klasifikasi sangat baik. Penerapan pengembangan bahan ajar dengan kategori baik sekali, yaitu 29 atau 90,62\% perhatian siswa terhadap materi yang disampaikan dan keaktifan siswa termasuk dalam kategori baik sekali sebanyak 30 atau 93,75\% siswa. Kualitas penerapan pengembangan bahan ajar model kooperatif tipe round table dalam pembelajaran 100\% dengan klasifikasi sangat baik dan hasil analisis nilai post-test sebesar 96,87\% menunjukan bahwa perangkat pembelajaran yang digunakan memiliki kualitas praktis dan perangkat pembelajaran yang dikembangkan memiliki kualitas efektif persentase ketuntasan siswa lebih dari $75 \%$.

Kata kunci: pengembangan, menulis deskripsi, model kooperatif round table
\end{abstract}




\section{A. PENDAHULUAN}

Pembelajaran menulis di sekolah memiliki peranan yang sangat penting sebagai dasar keterampilan menulis siswa. Keterampilan menulis merupakan keterampilan yang harus mendapatkan perhatian karena menuntut kecerdasan dan kreativitas. Tanpa kreativitas mustahil bagi seseorang untuk bisa menghasilkan karya yang baik sebab menulis merupakan proses kreatif yang harus diasah secara terus-menerus. Hal ini selaras dengan pendapat Nurgiyantoro (2010, hal. 422) yang menyatakan bahwa aktivitas menulis merupakan suatu bentuk manifestasi kemampuan dan keterampilan berbahasa yang paling akhir dikuasai oleh pelajar bahasa setelah kemampuan mendengarkan, berbicara, dan membaca. Dibandingkan dengan tiga kemampuan berbahasa yang lain, kemampuan menulis lebih sulit dikuasai bahkan oleh penutur asli bahasa yang bersangkutan sekalipun. Hal ini disebabkan kemampuan menulis menghendaki penguasaan berbagai unsur kebahasaan dan unsur di luar bahasa itu sendiri yang akan menjadi isi karangan.

Keterampilan menulis haruslah menghasilkan sebuah produk berupa tulisan, oleh karena itu keterampilan menulis seringkali dianggap sebagai keterampilan berbahasa yang paling sulit diantara keterampilan berbahasa lainnya. Hal tersebut selaras dengan pendapat Mulyati dkk (2009, hal. 1.13) menyatakan bahwa menulis adalah keterampilan produktif dengan menggunakan tulisan. Menulis dapat dikatakan suatu keterampilan berbahasa yang paling rumit diantara jenis-jenis keterampilan berbahasa lainnya. Ini karena menulis bukanlah sekadar menyalin kata-kata dan kalimat-kalimat; melainkan juga mengembangkan dan menuangkan pikiran-pikiran dalam suatu struktur tulisan yang teratur.

Kegiatan menulis merupakan kegiatan yang melibatkan pikiran dan perasaan yang kemudian dituangkan ke dalam bentuk-bentuk grafis dengan menggunakan bahasa yang komunikatif sehingga pembaca dapat mengerti dan memahami apa yang disampaikan. Setidaknya ada tiga hal yang ada dalam aktivitas menulis, yaitu adanya ide atau gagasan yang melandasi seseorang untuk menulis, adanya media berupa bahasa tulis, dan adanya tujuan menjadikan pembaca memahami pesan atau informasi yang disampaikan oleh penulis (Suparno, 2011, hal. 12).

Zainurrahman (2013, hal. 2) menjelaskan bahwa kegiatan menulis merupakan salah satu dari empat keterampilan berbahasa yang mendasar (berbicara, mendengar, menulis, dan membaca). Diantara keterampilan berbahasa yang lain, menulis merupakan salah satu keterampilan yang tidak dikuasai oleh setiap orang, apalagi menulis dalam konteks akademik (academic writing), seperti menulis esai, karya ilmiah, laporan penelitian, dan sebagainya.

Suparno (2011, hal. 14) menjelaskan bahwa manfaat menulis antara lain untuk: (1) menulis sebagai peningkatan kecerdasan, yaitu daya naluri berjalan mengeluarkan ide-ide dan mengingat-ingat informasi yang pernah didapat; (2) menulis dapat mengembangkan daya inisiatif dan kreativitas, yaitu mampu melihat suatu fenomena alam, yang dituangkan ke dalam tulisan dan mendokumentasikan; (3) menulis dapat menumbuhkan keberanian; dan (4) menulis dapat mendorong untuk mencari dan mengumpulkan informasi. tulisan yang baik, diantaranya adalah jelas, ekonomis, memiliki kesatuan organisasi yang baik, menggunakan pemakaian bahasa yang dapat diterima, dan mengikuti kaidah gramatikal. Ciri dasar tersebut dapat dijadikan sebagai acuan membuat tulisan yang baik.

Pada dasarnya menulis karangan dekripsi paling mudah di antara menulis karangan yang lain seperti menulis 
karangan argumentasi, eksposisi, narasi, dan lain-lain. Namun demikian, banyak siswa yang kurang mengembangkan kerangka berfikir dengan tulisan, selain itu juga siswa banyak yang kesulitan dalam mendapatkan ide, dan masih banyak siswa yang menganggap bahwa pelajaran menulis sulit. Oleh karena itu, guru perlu mencari upaya yang dapat membuat siswa dapat menulis dengan baik. Siswa masih banyak yang menganggap bahwa menulis deskripsi susah dan pelajaran menulis membosankan.

Deskripsi adalah tulisan yang menggambarkan suatu objek sedetaildetailnya secara mendalam dan sistematis sesuai dengan keadaan yang sebenarbenarnya tentang suatu yang digambarkan tersebut sehingga pembaca seakan-akan melihat, ,erasakan, atau mengalami langsung objek tersebut. Tarigan (2011, hal. 54-55) menyatakan bahwa berdasarkan bentuknya deskripsi dibagi menjadi dua, yakni pemerian faktual dan pemerian pribadi. Pemerian faktual adalah pemerian yang berdasarkan fakta-fakta sesungguhnya. Pemarian faktual beranggapan bahwa subtansisubtansi material atau haikat-hakikat kebendaan ada dalam keberadaan yang bebas dari yang melihatnya. Orang, tempat, bintang, bangunan, dan pemandangan dapat dilukiskan atau diperiksa secara tepat dan objektif seperti keadaan yang sebenarnya, tanpa menghiraukan persepsi-persepsi, asosiasiasosiasi, serta kesan-kesan pribadi dalam kesan dalam hati seorang penulis tertentu. Secara singkat dan tegas, pemerian factual haruslah menyatakan apa adanya, tidak ditambahi, dan tidak dikurangi. Informasi disajikan secara jelas dan objektif.

Tujuan dalam penelitian ini adalah (1) mengetahui pengembangan bahan ajar model kooperatif tipe round table dapat meningkatkan kemampuan menulis deskripsi pada siswa kelas X SMA; (2) mengetahui bahan ajar model kooperatif tipe round table dapat meningkatkan kemampuan menulis deskripsi pada siswa kelas X SMA; dan (3) mengetahui kualitas penerapan bahan ajar model kooperatif tipe round table dengan media audio dapat meningkatkan hasil pembelajaran menulis deskripsi siswa kelas X SMA.

Tipe round table ini adalah salah satu model pembelajaran kooperatif yang dikembangkan oleh Spencer Kagan. Round table merupakan teknik menulis yang menerapkan pembelajaran dengan menunjuk tiap-tiap anggota kelompok untuk berpartisipasi secara bergiliran dalam kelompoknya dengan membentuk meja bundar atau duduk melingkar (Cafferty, 2006, hal. 191).

Cooperative round table mengandung pengertian bekerja sama dengan mencapai tujuan bersama (Hamid Hasan dan Solihatin dan Raharja, 2014, hal. 4). Dalam kegiatan Cooperative round table siswa secara individu mencari hasil yang menguntungkan bagi seluruh anggota kelompoknya. Sehubungan dengan pengertian tersebut, Slavin menyatakan bahwa "Cooperative round table adalah suatu metode pembelajaran dimana siswa belajar dan bekerja dalam suatu kelompokkelompok kecil secara kooperatif yang anggotanya terdiri dari 4 sampai 6 orang. Model pembelajaran cooperative round table ini menekankan pada pemberian kesempatan belajar yang lebih luas dan suasana yang kondusif kepada siswa untuk memperoleh serta mengembangkan pengetahuan, sikap, nilai dan keterampilan sosial yang bermanfaat dengan menggunakan model cooperative round table, siswa bukan hanya belajar dan menerima apa yang disajikan oleh guru dalam pembelajaran, melainkan dapat belajar dari siswa lainnya serta mempunyai kesempatan untuk membelajarkan siswa yang lain (Solihatin dan Raharjo, 2014, hal. 9).

Baskoro (2008, hal. 12) media pembelajaran adalah segala sesuatu yang dapat digunakan untuk menyalurkan 
pesan yang dapat merangsang pikiran, perasaan, perhatian dan kemauan seseorang sehingga dapat mendorong terjadinya proses belajar mengajar sesuai dengan tujuan yang telah ditetapkan. Penelitian ini menggunakan media audiovisual, yaitu media pembelajaran yang mengombinasikan slide dan suara. Arsyad (2015, hal. 146) menjelaskan media pembelajaran penggabungan ini merupakan gabungan slide (film bingkai) dengan tape audio adalah jenis sistem multimedia yang paling mudah diproduksi. Sistem multimedia ini serba guna, mudah digunakan, dan cukup efektif untuk pembelajaran kelompok atau pembelajaran perorangan dan belajar mandiri. Jika didesain dengan baik, sistem multimedia gabungan slide dan tape dapat membawa dampak dramatis dan tentu saja dapat meningkatkan hasil belajar.

Penggunaan media pembelajaran ini dapat digunakan di mana pun untuk berbagai pencapaian tujuan pembelajaran. Gambar-gambar berupa slide ditampilkan untuk menyampaikan informasi agar memunculkan respons siswa. Gambargambar yang berupa slide bisa disertai dengan narasi yang sesuai sebagai pengantar dan pembelajaran dari satu unit pembelajaran.

\section{B. METODE}

Penelitian ini merupakan penelitian pengembangan atau Research \& Development (R\&D). Research and Development adalah metode penelitian yang digunakan untuk menghasilkan produk tertentu dan menguji keefektifan produk tersebut (Sugiyono, 2012, hal. 104). Penelitian dan pengembangan merupakan metode penelitian yang digunakan untuk mengembangkan atau memvalidasi produk-produk yang digunakan dalam pendidikan dan pembelajaran. Model 4D terdiri dari empat tahap, yaitu: define (pendefinisian), design (perancangan), develop (pengembangan), dan disseminate (penyebaran).

Subjek penelitian tindakan ini adalah peserta didik kelas X IPA-1 dan guru pengampu mata pelajaran bahasa Indonesia sebagai kolaborator di SMA Negeri 2 Tenggarong. Objek penelitian ini adalah pembelajaran keterampilan menulis deskripsi kelas X IPA-1 SMA Negeri 2 Tenggarong. Instrumen yang digunakan pada penelitian ini adalah lembar penilaian perangkat pembelajaran, angket respons siswa, lembar observasi keterlaksanaan kegiatan pembelajaran, dan tes kemampuan pemecahan masalah siswa. Angket respons siswa menggunakan skala likert 1-5 dengan lima alternatif jawaban, yaitu Sangat Kurang (SK), Kurang (K), Cukup (C), Baik (B), dan Sangat Baik (SB).

Angket tersebut dinyatakan valid dan layak untuk digunakan jika aspek kepraktisan perangkat pembelajaran dilaksanakan dengan menarik dan menyenangkan, siswa aktif berpartisipasi dalam proses pembelajaran menulis deskripsi, mampu bekerja sama, dan siswa paham tentang pembelajaran menulis deskripsi dengan model kooperatif tipe round table.

\section{PEMBAHASAN}

Validasi oleh ahli materi bertujuan untuk mengetahui validitas bahan ajar yang dikembangkan serta menghasilkan perangkat pembelajaran draft II. Guru ahli dibedakan menjadi dua, yaitu guru ahli materi dan ahli media. Guru ahli materi melakukan validasi bahan ajar dari aspek kelayakan isi, penyajian materim aspek kebahasaan dan kegrafikaan. Data penilaian keseluruhan pada setiap aspek dari seluruh validator disajikan dalam tabel berikut ini. 
Tabel 1. Data Penilaian Bahan Ajar Keseluruhan Aspek dari Validator

\begin{tabular}{clccc}
\hline \multirow{2}{*}{ No } & \multirow{2}{*}{ Aspek } & \multicolumn{2}{c}{ Validator } & \multirow{2}{*}{ Rata-Rata } \\
\cline { 3 - 4 } & & Ahli Materi & Ahli Media & \\
\hline 1 & Kelayakan isi/Materi & 4,69 & 4,77 & 4,73 \\
2 & Kelayakan Penyajian & 4,83 & 4,67 & 4,75 \\
3 & Kelayakan Kebahasaan & 4,75 & 4,75 & 4,75 \\
4 & Kelayakan Kegrafikan & 4,67 & 4,78 & 4,73 \\
\hline Jumlah & $\mathbf{1 8 , 9 4}$ & $\mathbf{8 , 9 7}$ & \\
Rata-Rata & $\mathbf{4 , 7 4}$ & $\mathbf{4 , 7 4}$ & $\mathbf{4 , 7 4}$ \\
Persentase & $\mathbf{9 4 , 7 \%}$ & $\mathbf{9 4 , 8 5 \%}$ & $\mathbf{9 4 , 7 8 \%}$ \\
\hline
\end{tabular}

Berdasarkan data dalam tabel diatas dapat diketahui bahwa kualitas bahan ajar berdasarkan penilaian secara keseluruhan menunjukkan kriteria sangat baik dengan skor rata-rata 4,74 atau 94,78\% dari skor rata-rata maksimal 5,00 .
Klasifikasi bahan ajar yang memenuhi kriteria sangat baik menunjukkan bahwa bahan ajar memenuhi kualifikasi valid sehingga bahan ajar yang telah dikembangkan layak digunakan dalam pembelajaran di sekolah.

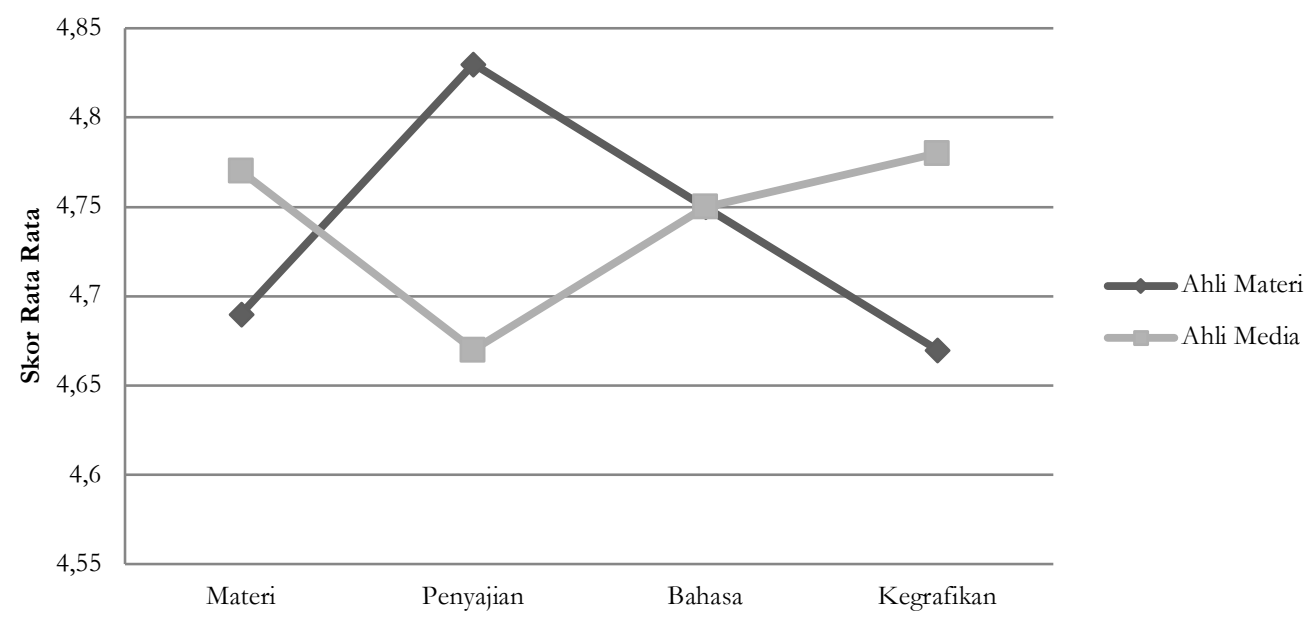

Gambar 1. Grafik hasil validasi Ahli Materi dan Media

Dari grafik tersebut terlihat bahwa hasil validasi yang dilakukan oleh ahli materi pada aspek kelayakan materi, kelayakan penyajian. Kelayakan kebahasaan dan kelayakan kegrafikab menunjukkan hasil sangat baik, begitu juga hasil validasi yang dilakukan oleh ahli media. 


\section{Tabel 2. Pengamatan Penerapan Pengembangan Bahan Ajar Model Kooperatif Tipe Round Table pada Sikap Belajar Siswa}

\begin{tabular}{llll}
\hline \multicolumn{1}{c}{$\begin{array}{c}\text { Situasi } \\
\text { Kegiatan Pembelajaran }\end{array}$} & \multicolumn{1}{c}{ Indikator } & Ya & Tidak \\
\hline a. $\quad$ Aktivitas belajar & $\begin{array}{l}\text { Keantusiasan siswa dalam mengikuti } \\
\text { pembelajaran }\end{array}$ & $29(90,63 \%)$ & $3(9,37 \%)$ \\
b. Perhatian & $\begin{array}{l}\text { Perhatian siswa terhadap materi yang } \\
\text { disampaikan }\end{array}$ & $30(93,75 \%)$ & $2(6,25 \%)$ \\
c. $\quad$ Keaktifan & Peran siswa dalam kegiatan pembelajaran & $30(93,75 \%)$ & $2(6,25 \%)$ \\
\hline
\end{tabular}

Sikap siswa dalam mengikuti pembelajaran menulis deskripsi sudah cukup baik dibandingkan pada pelaksanaan prasiklus, hal itu dapat dibuktikan dari hasil observasi sikap belajar siswa, yang berantusias mengikuti pembelajaran masuk dalam kategori baik sekali 29 atau 90,62\% siswa. Perhatian siswa terhadap materi yang disampaikan dan keaktifan siswa termasuk dalam kategori baik sekali sebanyak 30 atau 93,75\% siswa.

Berdasarkan hasil lembar observasi keterlaksanaan diperoleh hasil persentase $100 \%$, meningkat jika dibandingkan dengan persentase pada pertemuan pertama, yaitu $73,33 \%$.

\section{Tabel 3. Rincian Kegiatan Pernyataan Angket Lembar Observasi Keterlaksanaan Pembelajaran}

\begin{tabular}{lcc}
\hline \multicolumn{1}{c}{ Kegiatan } & Pertemuan $\mathbf{1}$ & Pertemuan II \\
\hline Pendahuluan & 3 & 3 \\
Inti & 7 & 9 \\
Penutup & 1 & 3 \\
Jumlah & 11 & 15 \\
Persentase & $73,33 \%$ & $100 \%$ \\
\hline
\end{tabular}

Tabel 4. Analisis Tes Kemampuan Pemecahan Masalah Siswa

\begin{tabular}{|c|c|c|c|}
\hline \multirow{2}{*}{ No } & \multirow{2}{*}{ Perhitungan } & \multicolumn{2}{|c|}{ Skor } \\
\hline & & Pretest & Posttest \\
\hline 1. & Nilai terendah & 28 & 63 \\
\hline 2. & Nilai tertinggi & 78 & 95 \\
\hline 3. & Jangkauan & 50 & 32 \\
\hline 4. & Rata-rata skor tiap indikator & & \\
\hline & a. Memahami masalah & $62,70 \%$ & $100 \%$ \\
\hline & b. Merencanakan penyelesaian masalah & $55,08 \%$ & $76,37 \%$ \\
\hline & c. Menyelesaikan masalah sesuai rencana & $48,63 \%$ & $77,54 \%$ \\
\hline & d. Memeriksa kembali & $29,49 \%$ & $68,55 \%$ \\
\hline 5. & Rata-rata nilai kemampuan pemecahan masalah & $48,97 \%$ & $80,66 \%$ \\
\hline 6. & Banyak siswa tuntas & 2 & 30 \\
\hline 7. & Banyak siswa tidak tuntas & 31 & 1 \\
\hline 8. & Persentase ketuntasan & $3 \%$ & $96,87 \%$ \\
\hline
\end{tabular}

Berdasarkan hasil analisis nilai pretest dan posttest, diperoleh hasil persentase ketuntasan siswa pada posttest $84 \%$, meningkat jika dibandingkan dengan persentase ketuntasan siswa pada pretest, yaitu 3\%. Contoh pekerjaan siswa pada 
pretest dan posttest serta hasil perhitungan pretest dan posttest disajikan pada lampiran. Rata-rata kemampuan pemecahan masalah siswa adalah 80,66\%. Berdasarkan pedoman kualifikasi skor kemampuan pemecahan masalah skor rata-rata tersebut memiliki kategori baik.

Persentase ketuntasan minimal sebesar $84 \%$ yang memenuhi kriteria sangat baik dan persentase rata-rata kemampuan pemecahan masalah 80,66 yang memenuhi kriteria baik menunjukkan bahwa perangkat pembelajaran yang dikembangkan efektif ditunjau dari kemampuan pemecahan masalah.

Penerapan pengembangan bahan ajar model kooperatif tipe round table dalam meningkatkan kemampuan menulis deskripsi dengan klasifikasi bahan ajar yang memenuhi kriteria sangat baik dan menunjukkan kualifikasi valid sehingga bahan ajar yang telah dikembangkan layak digunakan dalam pembelajaran di sekolah. Petunjuk belajar pada bahan ajar cukup dipahami oleh siswa, namun sesekali peneliti harus menjelaskan kepada siswa yang masih mengalami kesulitan. Selama proses pembelajaran berlangsung siswa juga tidak ragu untuk bertanya. Pada kegiatan tindakan setiap siklus, sikap siswa dalam mengikuti pembelajaran menulis deskripsi sudah cukup baik dibandingkan pada pelaksanaan prasiklus, hal itu dapat dibuktikan dari hasil observasi sikap belajar siswa, yang berantusias mengikuti pembelajaran masuk dalam kategori baik sekali 29 atau $90,62 \%$ siswa. Perhatian siswa terhadap materi yang disampaikan dan keaktifan siswa termasuk dalam kategori baik sekali sebanyak 30 atau $93,75 \%$ siswa.

Kualitas penerapan pengembangan bahan ajar model kooperatif tipe round table dapat meningkatkan kemampuan menulis deskripsi pada siswa kelas $\mathrm{X}$ SMA. Analisis keprkatisan penerapan bahan ajar diperoleh dari hasil lembar observasi keterlaksanaan kegiatan pembelajaran dan angket siswa. Praktis menurut Nasution (2010, hal. 12) dapat diartikan bahwa bahan ajar yang dikembangkan dapat membantu dan membeikan kemudahan bagi penggunanya. Hasil lembar observasi kegiatan pembelajaran pertemuan pertama dan kedua, secara berturut-turut menunjukkan persentase $73,33 \%$ dan $100 \%$, Rata-rata hasil lembar observasi keterlaksanaan kegiatan pembelajaran menunjukkan persentase 100\% dengan klasifikasi sangat baik.

Persentase ketuntasan siswa lebih dari $75 \%$, selain menghitung persentase ketuntasan siswa, juga dilakukan analisis persentase untuk setiap indikator kemampuan pemecahan masalah. Indikator memahami masalah mengalami peningkatan dari rata-rata $62,70 \%$ menjadi $100 \%$. Indikator merencanakan penyelesaian masalah mengalami peningkatan dari rata-rata 55,08\% menjadi $76,37 \%$. Indikator menyelesaikan masalah sesuai rencana mengalami peningkatan dari rata-rata 48,63\% menjadi $77,54 \%$. Indikator memeriksa kembali mengalami peningkatan dari ratarata $29,49 \%$ menjadi $68,55 \%$. Secara keseluruhan, kemampuan pemecahan masalah mengalami peningkatan dari rata-rata $48,97 \%$ menjadi $80,66 \%$. Selain peningkatan kemampuan pemecahan masalah untuk setiap indikatornya, persebaran kemampuan pemecahan masalah siswa menjadi lebih kecil, rentang kemampuan pemecahan masalah paling tinggi dan paling rendah tidak besar. Hal ini menunjukan bahwa cooperative round table membantu siswa mengembangkan keterampilan penyelidikan dan pemecahan masalah (Kurniati, 2014, hal. 97).

\section{PENUTUP}

Pengembangan bahan ajar model kooperatif tipe Round Table pada materi menulis deskripsi dilakukan dengan mengacu pada model pengembangan 4- 
D. Penilaian bahan ajar oleh guru ahli media dan guru bahasa Indonesia diperoleh skor rata-rata 4,74 dari skor rata-rata maksimal 5,00 dengan klasifikasi sangat baik. Penerapan menulis deskripsi dengan kriteria sangat baik menunjukkan bahwa bahan ajar memenuhi kualifikasi valid sehingga layak digunakan dalam pembelajaran di sekolah. Sikap siswa dalam mengikuti pembelajaran menulis deskripsi sudah mengalami peningkatan, antusias siswa mengikuti pembelajaran masuk dalam kategori baik sekali 29 atau $90,62 \%$ dan perhatian siswa terhadap materi yang disampaikan dan keaktifan siswa termasuk dalam kategori baik sekali sebanyak 30 atau 93,75\% siswa.

Kualitas penerapan pengembangan bahan ajar model kooperatif tipe round table membantu dan memberikan kemudahan bagi penggunanya. Rata-rata hasil lembar observasi keterlaksanaan kegiatan pembelajaran menunjukkan persentase $100 \% \%$ dengan klasifikasi sangat baik dan hasil analisis nilai pretest dan post-test menunjukkan persentase ketuntasan siswa pada post-test sebesar $96,87 \%$, sedangkan persentase ketuntasan siswa pada pretest sebesar 3\%. Hal ini menunjukkan bahwa bahan ajar yang dikembangkan memiliki kualitas efektif dan dapat membatu siswa mencapai kompetensi yang harus dimilikinya.

\section{DAFTAR PUSTAKA}

Arsyad, A. (2015). Media pembelajaran. Jakarta: Raja Grafindo Persada.

Baskoro, E. (2008). Media Pembelajaran. Cirebon: Uswaganti Press.

Cafferty, \& Steven, G. (2006). Cooperative Learning dan Second Languange Teaching. New York: Cambridge University Press.

Kurniati, T. (2014). Penerapan Model Pembelajaran Kooperatif Tipe Round table dalam Peningkatan Pembelajaran Bahasa Jawa pada Siswa Kelas V SD Negeri Entak. Jurnal Kalam Cendikia, 6(1). https://jurnal.fkip.uns.ac.id/index.ph $\mathrm{p} /$ pgsdkebumen/article/view/3840

Mulyati,Y. (2009). Keterampilan Berbahasa Indonesia di SD. Jakarta: Universitas Terbuka.

Nasution, S. (2010). Berbagai Pendekatan dalam Proses Belajar dan Mengajar. Jakarta: Bumiaksara.

Novita, I. (2020). Pengembangan Bahan Ajar Menulis Teks Cerpen Berdasarkan Teknik Storyboard pada Siswa Kelas XI SMA. Diglosia: Jurnal Kajian Bahasa, Sastra, dan Pengajarannya, 3(1), 46-52. https://doi.org/10.30872/diglosia.v $\underline{3 i 1.29}$

Nurgiyantoro, B. 2010. Penilaian dalam Pengajaran Bahasa dan Sastra. Yogyakarta: BFFE.

Rajja. (2020). Pengembangan Bahan Ajar Menulis Teks Cerpen dengan Metode Cerpen-gram untuk Siswa Kelas IX di Kecamatan Muara Wahau. Diglosia: Jurnal Kajian Bahasa, Sastra, dan Pengajarannya, 3(1), 24-32. https://doi.org/10.30872/diglosia.v $\underline{3 i 1.26}$

Sari, L. K. (2019). Pengembangan Pembelajaran Menulis Teks Ceramah Dengan Model Problem Based Learning Dipadukan Media Gambar Pada Siswa Kelas XI SMA. Diglosia: Jurnal Kajian Babasa, Sastra, Dan Pengajarannya, 2(1), 59-72. https://doi.org/10.30872/diglosia.v $\underline{2 \mathrm{i} 1.18}$

Solihatin, Etin \& Raharjo. (2014). Cooperative Learning Analisis Model Pembelajaran IPS. Jakarta: Bumi Aksara.

Sugiyono. (2012). Metode Penelitian Kuantitatif, Kualitatif dan R\&D. Bandung: Alfabeta.

Suparno. (2012). Keterampilan Dasar Menulis. Jakarta: Universitas Terbuka.

Sutriyati. (2019). Pengembangan Bahan Ajar Menulis Esai Dengan Memanfaatkan Kearifan Lokal Melalui Pembelajaran Berbasis 
Proyek (PBP) Siswa SMA. Diglosia: Jurnal Kajian Bahasa, Sastra, dan Pengajarannya, 2(1), 39-46. https://doi.org/10.30872/diglosia.v $\underline{2 i 1.16}$
Tarigan, H. G. (2011). Menulis Sebagai Kerampilan Berbahasa. Bandung: Angkasa.

Zainurrahman. (2013). Menulis: Dari Teori Hingga Praktik. Bandung: Alfabeta. 
